\title{
Economic Analysis of Silkworm Rearing and Cocoon Production in Bilaspur District of Himachal Pradesh
}

\author{
Vikalp Sharma*, Megha Rattan and S.K. Chauhan
}

Department of Agricultural economics, Extension Education and Rural Sociology, CSKHPKV, Palampur, Himachal Pradesh, India

*Corresponding author: vsvikalp@gmail.com (ORCID ID: 0000-0003-3382-9846)

Received: $13-04-2019$

Revised: $17-07-2019$

Accepted: 27-08-2019

\begin{abstract}
Sericulture is an agro-based multitudinous activity which involves cultivation of mulberry, production of laying, rearing of silkworms for cocoons, marketing and reeling of cocoons for value added products such as processing and weaving of the yarn. It is a short gestation period labour intensive enterprise which can go a long way in promoting inclusive growth and alleviating poverty in rural areas. The present study was therefore carried out in order to analyse investment and returns pattern of cocoon production in Bilaspur district of Himachal Pradesh. Two-stage random sampling and proportional allocation method was used to prepare a list of sample farmers. Out of 60 silkworm rearers, 19 were large and 41 were small. The dry cocoon production per farm on small and large category was estimated at $8.25 \mathrm{~kg}$ (6.20 kg in spring and $2.05 \mathrm{~kg}$ in autumn) and $19.51 \mathrm{~kg}(16.67 \mathrm{~kg}$ in spring and $2.84 \mathrm{~kg}$ in autumn). The dry cocoon production per ounce of seed was found to be $20.28 \mathrm{~kg}$ and $26.14 \mathrm{~kg}$ on small and large category households for both the seasons together. The fixed cost of production / ounce for spring crop varied from 9.92 per cent on small farms to 14.75 per cent on large farms. The variable cost varied from 90.08 per cent on small farms to 85.25 per cent on large farms implying the economical use of fixed and variable resources by large growers. The gross returns per ounce seed basis ranged between ₹ 1,626 and ₹ 5,535 on small and large farms for the spring crop. The autumn crop was found to give negative returns; therefore farmers should be provided with technology which could reduce the moisture in the rearing room, develop humidity resistant races of silkworms as well as develop varieties of mulberry plantation which may yield good leaves just after rainy season.

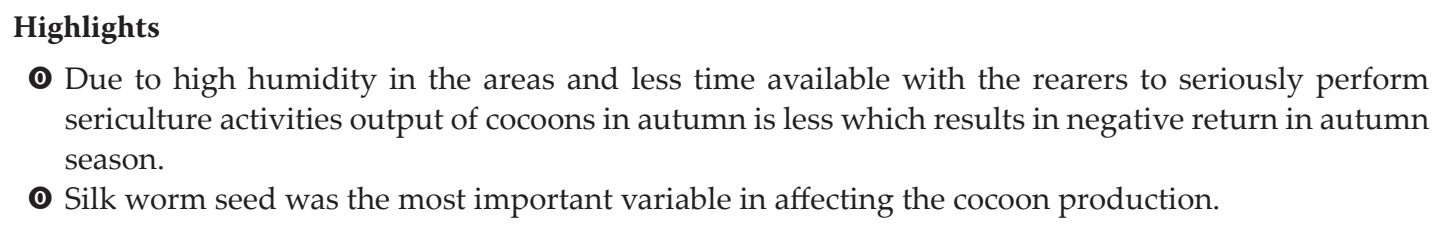

Keywords: Sericulture, rearing house, plantation, silkworm, cost and returns

The diversification of rural economy in general and agriculture sector in particular has become essential to boost income and employment opportunities of the rural masses. It is being increasingly realized that various crop rotations like the paddy- wheat or maize- wheat cannot be sustainable and are causing degradation of natural resources, particularly soil and ground water. There is enough evidence to indicate that intensive agriculture has rendered vast tracts of land uncultivable. The marginal and small farms are worst affected in this process. It is, therefore imperative to explore alternative income and employment opportunities for the rural masses in general and for weaker sections in particular to reduce their dependence on agriculture. Sericulture is one among the several enterprises that can provide economic sustenance to the weaker sections of the society like marginal and small farmers. Sericulture in India is an old age practice and India has unique distinction of producing all the four 
AESRA

commercially known varieties of silk viz; mulberry, tasar, eri and muga. India is the second largest producer of silk next to China accounting for more than 15 per cent of the global raw silk production. The total annual production of raw silk output per annum aggregates to 28.71 thousand tonnes according to 2014 figures. Mulberry silk producing states are Karnataka (43\%), Andhra Pradesh (32\%), West Bengal (7\%), Tamil Nadu (10\%) and Jammu and Kashmir $(0.62 \%)$ which together accounts for approximately 93 per cent of the country's total mulberry raw silk production.

Sericulture is a highly labour intensive industry. It is targeted to provide direct or indirect employment to about 9.24 million people in India by The Central Silk Board 2016-17. It requires low investment and offer high profit, provides regular income to farmers throughout the year unlike most other agricultural crops; it has an assured and ever increasing demand which is bound to grow further in the wake of liberalization and growing middle class; it helps in diverting the income from urban/rural riches to the rural poor. All these features render it easily adaptable by economically poor and socially marginalized people. Given due importance, it can prove to be effective tool in accelerating the growth of rural economy.

In Himachal Pradesh, the beginning of sericulture was made during 1951 in populous low and mid altitude areas. Sericulture activities are spread over in ten of the twelve districts. Endowed with favourable temperature varying from 30 to $42^{\circ} \mathrm{C}$ and conditions for mulberry growth and silkworm rearing, the sericulture is developing as an important rural income generating subsidiary occupation to augment the income of the agrarian community. The State is predominantly a bivoltine silk producing area and has a salubrious climate to produce superior quality bivoltine cocoons for quality silk. Currently, it is practiced in 1900 villages covered under sericulture divisions namely, Dehra, Mandi, Nadaun, Palampur, Shimla, Ghumarwin and Dhaulakuan. It provides part time employment to about 9000 families of whom mostly belong to the marginalized and economically vulnerable sections of the society. Among the districts practicing sericulture, district Bilaspur is the biggest producer of silk-cocoons, sharing 35.0 per cent production followed by Mandi (25.0 \%), Kangra (22.0\%) and
Hamirpur (16.0\%). Since long, no systematic study revealing economic aspects has been carried out in the state. Therefore, the present study has been carried out with the following specific objectives:

\section{MATERIALS AND METHODS}

Bilaspur district of Himachal Pradesh was purposively selected for the study. Two- stage random sampling design was employed for the selection of sample villages. Ten villages (three villages from Auhar, three from Kandraur and four from Singasiwin were selected at random) were chosen through proportional allocation as first stage of sampling. In each of the selected village, a complete list of sericulture farmers was prepared along with silkworm seed reared by them. From these villages, a random sample of 60 silkworm rearers was chosen through proportional allocation. The entire sample was divided into two categories viz., small rearers (upto 0.5 ounce) and large rearers (>0.5 ounce) based on the amount of silk seed reared. Out of these, 41 comprised to small and 19 to large category. The research was conducted in 2016.

\section{Cost of production and net returns}

To examine the economic viability, the cost of production and net returns of cocoon production were computed as under.

\section{Fixed costs}

These costs refer to those which remain unchanged over a short period of time. Fixed costs considered in present study included depreciation on implements and building @ 12\% and 3\% per annum, respectively and interest on fixed capital @ 8\% per annum.

\section{Variable costs}

Variable costs are those costs which vary with the level of production. In making production decisions in the short run, only variable costs were needed to be considered which include cost of silkworms (these are supplied on highly subsidized rates i.e.; @ ₹ 80/ounce), cost of mulberry leaves, charges of labour utilization, cost of chemicals use if any, value of miscellaneous items such as newspaper, twigs of bushes, wheat stalk etc.

\section{Computation of gross returns}

The total returns from the cocoon rearing were 
worked out by multiplying the per unit price with the total production.

$$
G R=Y_{C} P_{C}
$$

where, $G R=$ Gross returns from silk cocoons (in ₹)

$$
Y_{C}=\text { Yield of cocoon in kilograms }(\mathrm{kg})
$$$$
P_{C}=\text { Price of cocoon per kilogram }(\mathrm{kg})
$$

Net returns over variable cost $=$ Gross returns Variable cost

Net returns over total cost $=$ Gross returns - Total cost

\section{Break-even output}

Break-even output is that level of produce at which no profit and no loss situation prevails. The level was computed as follows:

$$
B E O=\frac{T F C}{A S P-A V C}
$$

where, $B E O$ is the break-even output in $\mathrm{kg}$ of cocoons

TFC is the total fixed cost in rupees

$A S P$ in the average selling price realized per $\mathrm{kg}$ of cocoons in rupees, and

$A V C$ is the average variable cost per $\mathrm{kg}$ of cocoons in rupees

\section{Functional analysis}

Factors affecting yield of cocoon were examined through regression technique. Both linear and CobbDouglas production functions were tried to examine the factors affecting the yield of cocoons but on the basis of number of significant variables and the higher value of coefficient of multiple determination $\left(\mathrm{R}^{2}\right)$, Cobb Douglas production function was considered to be the best fit, the functional form of which is given as under :

$$
Y=b_{0} X_{1}^{b 1} X_{2}^{b 2} X_{3}^{b 3} X 4^{b 4} X_{5}^{b 5} X_{6}^{b 6} e^{\mu}
$$

or

$$
\begin{aligned}
\log Y= & \log b_{0}+b_{1} \log X_{1}+b_{2} \log X_{2}+b_{3} \log X_{3}+ \\
& b_{4} \log X_{4}+b_{5} \log X_{5}+b_{6} \log X_{6}+\mu
\end{aligned}
$$

where, $Y=$ Cocoon production per farm in $\mathrm{Kg}$

$X_{1}=$ Human labour (man-days/farm)

$X_{2}=$ Silk seed used/farm for spring crop
$X_{3}=$ Mulberry leaf (quintals/farm)

$X_{4}=$ Experience of silkworm rearing in years

$X_{5}=$ Feeding schedule (number of times feed application)

$X_{6}=$ Rearing house (dummy variable: 10 for separate rearing house; 1 otherwise)

$b_{0}=$ Intercept term

$b_{1}$ to $b_{6}=$ Regression coefficients

$\mu=$ Error term

The regression coefficients derived from observations in logarithms, are the elasticities with respect to individual variables. Their sum indicated the nature of returns to scale. With the sum being equal to 1 , a given percentage increase in input results in proportional increase in output. With elasticity sums being more or less than one, implies that output will increase by a greater or smaller percentage respectively, than proportionate increase in inputs and depicted increasing and decreasing returns to scale. Coefficient of multiple determination $\left(\mathrm{R}^{2}\right)$ was computed to know the extent to which dependent variable got affected by all the explanatory variables. As the number of variables in the function increased, the value of $\mathrm{R}^{2}$ also got increased. Therefore, to overcome this problem, adjusted coefficient of multiple determination $\left(\bar{R}^{2}\right)$ was calculated as follows:

$$
\bar{R}^{2}=1-\left(1-R^{2}\right) \cdot \frac{N-1}{N-K}
$$

where, $\bar{R}^{2}=$ Adjusted coefficient of multiple determination

$R^{2}=$ Coefficient of multiple determination

$N=$ Number of sample observations used in the model

$K=$ Number of parameters estimated from the sample

The significance of $\mathrm{R}^{2}$ was tested with the help of F-test as under:

$$
F=\frac{R^{2}}{\frac{\left(1-R^{2}\right)}{(N-K)}} \sim F(K-1),(N-K)
$$

where, $N=$ Number of sample observations used in the model

$K=$ Number of bi's (including constant term $b_{0}$ ) 


\section{RESULTS AND DISCUSSION}

Costs and returns analysis is useful to examine the feasibility of investment to increase income. In the study area some of the sericulturists did not have adequate mulberry trees and bushes on their field bunds and on boundaries of their cultivated land and within non-cultivated lands; therefore, economics of mulberry cultivation has not been worked out. However, the efforts made by farmers in arranging mulberry leaves as well as cost incurred on collecting/ arranging leaves became the part of economics of silkworm rearing. In the present section an attempt has been made to present the average yield of cocoons, employment, income as well as cost of production of silkworm cocoons and returns realized. The investment pattern related to this enterprise has been discussed in earlier sections.

\section{Average yield of cocoons}

The average yield of cocoons realized by different size farms is presented in Table 1. It is evident from the table that average seed used by the farmers was $0.66 \mathrm{Oz}(18.48 \mathrm{gm})$ in spring season while the quantity reduced in the autumn to $0.28 \mathrm{Oz}(7.84$ gm). Also the dry cocoon production per farm on small and large category was estimated at 8.25 $\mathrm{kg}$ (6.20 kg in spring and $2.05 \mathrm{~kg}$ in autumn) and $19.51 \mathrm{~kg}$ (16.67 kg in spring and $2.84 \mathrm{~kg}$ in autumn) respectively which gave an overall average of 11.88 $\mathrm{kg}$ (9.52 kg in spring and $2.36 \mathrm{~kg}$ in autumn) in the study area. It is clear from the table that the spring season output was better than autumn one; the sericulturists in the former season obtained 84.26 per cent of the total output than the latter. As far as at the overall level, again the crop output per ounce of silk seed was higher i.e. $13.75 \mathrm{~kg}$ in spring than the autumn one which was $8.50 \mathrm{~kg}$. Across the farms, similar trend prevailed. On an average, the silk worms rearer could earn an income of ₹ 7,344 from cocoon harvest in which the share of spring crop was as high as 84.26. On small farms the contribution of spring crop was 80.03 per cent which increased to 88.62 per cent in case of large farms. Since the small farms had limited options for income and employment generation from different available resources so they were more inclined to autumn crop than their counter parts and as such the small farms could fetch almost one-fifth of income from autumn season crop output.
Table 1: Average yield of cocoons on sample farms

\begin{tabular}{|c|c|c|c|c|}
\hline \multirow{2}{*}{$\begin{array}{l}\text { S1. } \\
\text { No. }\end{array}$} & \multirow[t]{2}{*}{ Particulars } & \multicolumn{2}{|c|}{ Farm size } & \multirow[t]{2}{*}{ Overall } \\
\hline & & Small & Large & \\
\hline \multirow[t]{3}{*}{1} & $\begin{array}{l}\text { Silkworm worm seed } \\
\text { (ounce/farm) }\end{array}$ & & & \\
\hline & Spring & 0.50 & 1.00 & 0.66 \\
\hline & Autumn & 0.26 & 0.30 & 0.28 \\
\hline \multirow[t]{4}{*}{2} & $\begin{array}{l}\text { Cocoon Production }(\mathrm{Kg} / \\
\text { farm) }\end{array}$ & & & \\
\hline & Spring & 6.20 & 16.67 & 9.52 \\
\hline & Autumn & 2.05 & 2.84 & 2.36 \\
\hline & Total & 8.25 & 19.51 & 11.88 \\
\hline \multirow[t]{4}{*}{3} & $\begin{array}{l}\text { Cocoon production in }(\mathrm{Kg} / \\
\text { ounce of seed) }\end{array}$ & & & \\
\hline & Spring & 12.40 & 16.67 & 13.75 \\
\hline & Autumn & 7.88 & 9.47 & 8.50 \\
\hline & Total & 20.28 & 26.14 & 22.25 \\
\hline \multirow[t]{7}{*}{4} & Value of cocoons (₹/ farm) & & & \\
\hline & Spring @ ₹ 650 & 4030 & 10836 & 6188 \\
\hline & & $(80.03)$ & $(88.62)$ & $(84.26)$ \\
\hline & Autumn@₹490 & 1005 & 1391 & 1156 \\
\hline & & $(19.96)$ & $(11.38)$ & $(15.74)$ \\
\hline & Total & 5035 & 12227 & 7344 \\
\hline & & $(100.00)$ & $(100.00)$ & $(100.00)$ \\
\hline
\end{tabular}

Note: Figures in the parentheses indicate percentages of total in the respective category

It can be concluded from this table that the low output of cocoons per unit of silkworm seed in autumn was mainly due to high humidity in the areas and less time available with the rearers to seriously perform related activities because most of them were agriculturists also.

\section{Labour utilization pattern}

Since sericulture is a labour intensive enterprise, therefore, an attempt has been made to present the use of labour for performing various activities on the sample farms. It is clear from the table that 20 to 22 days of employment was generated through sericulture during a year (Table 2). At the overall level 15.93 was man days equivalent labour per farm basis was utilized for the spring crop and only 6.94 for autumn. Mulberry leaves collection activity was found to be the highly labour intensive as it alone accounted for 49.51 per cent and 50.58 per cent of the total labour utilization in spring and autumn season, respectively. Leaf pruning from the mulberry twigs and drying/sorting and storing 
Table 2: Activity wise labour utilization on sample farms (MD/farm)

\begin{tabular}{clcccccc}
\hline \multirow{2}{*}{ S1. No. } & \multicolumn{1}{c}{ Activity } & \multicolumn{2}{c}{ Small } & \multicolumn{2}{c}{ Large } & \multicolumn{2}{c}{ Overall } \\
\cline { 3 - 7 } & & \multicolumn{1}{c}{ Spring } & Autumn & Spring & Autumn & Spring & Autumn \\
\hline 1 & $\begin{array}{l}\text { Collection of mulberry } \\
\text { twigs from trees/bushes }\end{array}$ & $7.07(50.79)$ & $2.95(48.05)$ & $9.45(46.65)$ & $4.72(54.44)$ & $7.82(49.12)$ & $3.51(50.58)$ \\
2 & $\begin{array}{l}\text { Separation of leaves } \\
\text { from bushes }\end{array}$ & $1.11(7.97)$ & $0.46(7.49)$ & $2.96(14.61)$ & $0.59(6.81)$ & $1.70(10.65)$ & $0.50(7.22)$ \\
3 & Chopping of leaves & $0.65(4.67)$ & $0.24(3.91)$ & $0.88(4.34)$ & $0.34(3.92)$ & $0.72(4.54)$ & $0.27(3.91)$ \\
4 & Feeding of leaves & $0.94(6.75)$ & $0.51(8.31)$ & $1.36(6.71)$ & $0.49(5.65)$ & $1.07(6.74)$ & $0.50(7.26)$ \\
5 & $\begin{array}{l}\text { Bed cleaning, daily } \\
\text { watch \& ward }\end{array}$ & $0.78(5.60)$ & $0.46(7.49)$ & $1.29(6.37)$ & $0.62(7.15)$ & $0.94(5.91)$ & $0.51(7.36)$ \\
6 & Cocoon harvesting & $1.34(9.63)$ & $0.50(8.14)$ & $1.69(8.34)$ & $0.56(6.46)$ & $1.45(9.11)$ & $0.52(7.48)$ \\
7 & $\begin{array}{l}\text { Drying \& storage of } \\
\text { cocoons }\end{array}$ & $1.33(9.56)$ & $0.60(9.77)$ & $1.73(8.54)$ & $0.71(8.19)$ & $1.46(9.14)$ & $0.63(9.15)$ \\
8 & Sale of cocoons & $0.70(5.03)$ & $0.42(6.84)$ & $0.90(4.44)$ & $0.64(7.38)$ & $0.76(4.79)$ & $0.49(7.05)$ \\
\hline
\end{tabular}

Note: Figures in the parentheses indicate percentages of total in the respective category.

operations were the next in importance as far as labour utilization is concerned.

The similar scenario was observed across the farms. In small farms the spring crop utilized labour for 13.92 man days whereas it reduced to about 6.14 man days in autumn. On small farms, collection of mulberry after lopping was found to be the most labour intensive activity with its share of 50.79 per cent in spring and 48.05 per cent in autumn followed by cocoon harvesting with 9.63 per cent labour involvement. The large farms utilized labour for 20.26 man days equivalent in spring and 8.67 man days in autumn season. Again the collection of lopped mulberry branches utilized 46.65 per cent of labour in spring and 48.05 per cent in autumn followed by leaf pruning with 14.61 per cent in spring and 7.49 per cent in autumn. Lopping of mulberry branches and its transportation to the farm were the activities mostly performed by men and children. Pruning, chopping, feeding, bed cleaning etc. were women dominated activities on all the sample farms. Women with their nimble hands could perform the bed cleaning and mounting activities in a gentle way.

To conclude it can be stated that lopping of mulberry, its collection and transportation was the major labour intensive activity followed by cocoon harvesting, bed cleaning and daily watch and ward.

\section{Gender wise utilization of human labour}

Gender wise utilization of labour is presented in Table 3. The role of women was considered to be major in the sericulture enterprise. In all the cocoon crops raised in different seasons, most of the labour was performed by women. At the overall level, women contributed 54.76 per cent labour in spring and 57.01 per cent in autumn season. The women were followed by the men who most importantly performed the activity of collection of mulberry leaves with 26.62 per cent part in spring and 29.21 per cent in autumn crop. Children of different age group also contributed a lot in sericulture enterprise and their share in this enterprise was 18.62 per cent in spring and 13.78 per cent in autumn. Across the farms also same trend of labour utilization was observed where in women were the major participants in the silkworm rearing activity. On small farms, women contributed 56.46 per cent in spring and 63.52 per cent in the autumn season. While in the large farms, women still had their upper hand with 52.12 per cent involvement in spring and 47.06 per cent in autumn season.

It can be concluded from this table that women played a pivotal role in performing sericulture activities. Therefore, their contribution to the industry is colossal. Vasanthi 1992 has also reported that employment potential of women in sericulture 
Table 3: Gender wise labour utilization on sample farms (MD/farm)

\begin{tabular}{|c|c|c|c|c|c|c|c|}
\hline \multirow{3}{*}{ S1. No. } & \multirow{3}{*}{ Particulars } & \multicolumn{4}{|c|}{ Farm size } & \multirow{2}{*}{\multicolumn{2}{|c|}{ Overall }} \\
\hline & & \multicolumn{2}{|c|}{ Small } & \multicolumn{2}{|c|}{ Large } & & \\
\hline & & Spring & Autumn & Spring & Autumn & Spring & Autumn \\
\hline 1 & Men & $3.48(25.00)$ & $1.48(24.10)$ & $5.88(29.03)$ & $3.21(37.02)$ & 4.24 (26.62) & $2.03(29.21)$ \\
\hline 2 & Women & 7.87 (56.46) & $3.90(63.52)$ & $10.56(52.12)$ & $4.08(47.06)$ & $8.72(54.76)$ & $3.96(57.01)$ \\
\hline \multirow[t]{2}{*}{3} & Children & $2.57(18.53)$ & $0.76(12.38)$ & $3.82(18.85)$ & $1.38(15.12)$ & $2.97(18.62)$ & 0.96 (13.78) \\
\hline & Total & $13.92(100.00)$ & $6.14(100.00)$ & $20.26(100.00)$ & $8.67(100.00)$ & $15.93(100.00)$ & $6.94(100.00)$ \\
\hline
\end{tabular}

Note: Figures in the parentheses indicate percentages of total in the respective category.

is as high as 51 per cent and after realizing the magnitude of her contribution to production, the Government declared the year 1994 as 'Year of Women in Sericulture' with a basic intention of providing a due recognition for her role in the industry. She was provided development assistance like access to credit, inputs, subsidies and access to market.

\section{Costs and Returns}

Table 4 depicts the costs incurred per ounce on silkworm rearing and dry cocoon production. Dry cocoon weighed one- third of its green biomass. All the costs have been worked out on dry matter basis. The statistics shows that fixed cost was worked out to be more i.e. 11.62 per cent for autumn crop than 11.26 per cent for spring crop. Though in absolute form it was same i.e. ₹ 684/ Oz. Variable cost was the important one in all the sample farms and it varied from 90.08 per cent for spring crop on small farms to 85.25 per cent on large category. The corresponding figures for autumn crop were 88.25 per cent and 88.19 per cent on small and large farms, respectively. Labour was the important component of variable costs and it accounted for 75.80 per cent and 78.49 per cent of the total costs for spring and autumn crops on all the sample farms, respectively. The cost on mulberry leaves was worked out to be 8.66 per cent and 5.13 per cent for spring and autumn crops on all the farms, respectively. The expenses made on chemicals and waste newspaper were not much, rather, varied from 3 to 4 per cent. The total cost of cocoon production per ounce of silk seed was to the tune of ₹ 6,076 for spring crop and ₹ 5,887 for autumn crop.

Per ounce returns from cocoon production have also been presented in Table 4 . It can be observed from the table that total gross returns from spring silk worm rearing ranged from ₹ 8,060 on small farms to $₹ 10,836$ on large farms thus giving an overall average of ₹ 8,939 however, autumn crop showed only ₹ 3,861 on small farms to ₹ 4,640 in large farm with an overall average of $₹ 4,165$. Table 4 further revealed that a sericulturist on an average earned ₹ 13,104 as gross income from silk worm rearing in Bilaspur district. Spring crop showed positive net returns across the farms with ₹ 1, 626 for small, $₹ 5,535$ on the large farms and ₹ 2,863 at the overall level. The net returns over variable costs increased with the size of holding and costs declined with size of holding due to economies of scale. At the overall level, the sericulturists earned returns of ₹ 3,547 which varied from ₹ 2,264 on small to ₹ 6,314 on large farms in the spring season. However, the autumn crop gave to its opposite in all the sample farms. This crop showed negative net returns across the farms with ₹ 1,571 in small, ₹ 1,983 in large and $₹ 1,732$ at overall level. These returns still being negative increased a little bit while considering the net returns over variable cost. At the overall level the sericulturists earned returns to the extent of (-) ₹ 933 and (-) ₹ 782 and (-) ₹ 894 on small and large farms in the autumn season. The negative returns from autumn crop were due to very low average yield of cocoons. Break-even analysis performed for spring crop only indicated that sericulturist may get profit if they produce more than $3.49 \mathrm{~kg}$ of cocoons on small category and more than 2.62 $\mathrm{kg}$ on large with an overall average of $2.65 \mathrm{~kg}$ only and the reason being that the fixed cost component was very small. A perusal of Table 4 showed that spring crop was profitable in comparison to autumn on different category of farms. By growing cocoons in spring season one may fetch ₹ 2863 as net returns per ounce of silk seed raised, however, the autumn 
Table 4: Costs and returns from cocoon production on sample farms (₹/ounce)

\begin{tabular}{|c|c|c|c|c|c|c|c|}
\hline \multirow{3}{*}{$\begin{array}{l}\text { Sl. } \\
\text { No. }\end{array}$} & \multirow{3}{*}{ Particulars } & \multicolumn{4}{|c|}{ Farm size } & \multirow{2}{*}{\multicolumn{2}{|c|}{ Overall }} \\
\hline & & \multicolumn{2}{|c|}{ Small } & \multicolumn{2}{|c|}{ Large } & & \\
\hline & & Spring & Autumn & Spring & Autumn & Spring & Autumn \\
\hline 1 & Fixed cost & $\begin{array}{r}638 \\
(9.92) \\
\end{array}$ & 638 (11.75) & $782(14.75)$ & $782(11.81)$ & $684(11.26)$ & $684(11.62)$ \\
\hline & $\begin{array}{l}\text { Interest on fixed capital @ } 8 \% \text { for effective } \\
\text { period of } 30 \text { days }\end{array}$ & $\begin{array}{c}332 \\
(5.16)\end{array}$ & $332(6.11)$ & $455(8.58)$ & 455 (6.87) & $371(6.11)$ & $371(6.30)$ \\
\hline & $\begin{array}{l}\text { Depreciation on equipments and building @ } \\
12 \% \text { \& } 3 \% \text { respectively for effective period of } \\
30 \text { days }\end{array}$ & $\begin{array}{c}306 \\
(4.76)\end{array}$ & $306(5.64)$ & 327 (6.17) & $327(4.94)$ & $313(5.15)$ & $313(5.32)$ \\
\hline 2 & Variable cost & $\begin{array}{l}5796 \\
(90.08)\end{array}$ & $4794(88.25)$ & $\begin{array}{c}4519 \\
(85.25) \\
\end{array}$ & $5841(88.19)$ & $5392(88.74)$ & $5203(88.38)$ \\
\hline & Human labour & $\begin{array}{c}5012 \\
(77.90)\end{array}$ & $4250(78.24)$ & $\begin{array}{c}3647 \\
(68.80)\end{array}$ & $5202(78.54)$ & $4580(75.80)$ & 4621 (78.49) \\
\hline & Mulberry leaves* & $\begin{array}{c}492 \\
(7.65)\end{array}$ & $308(5.67)$ & $600(11.32)$ & $293(4.42)$ & $526(8.66)$ & 302 (5.13) \\
\hline & Chemicals & $\begin{array}{l}190 \\
(2.95)\end{array}$ & $158(2.91)$ & 217 (4.09) & $266(4.03)$ & 199 (3.27) & $201(3.41)$ \\
\hline & Waste newspaper & 78 (1.21) & $58(1.66)$ & $36(0.68)$ & $56(0.84)$ & $65(1.07)$ & $57(0.97)$ \\
\hline & $\begin{array}{l}\text { Interest on working capital for half } \\
\text { production period of cocoon crop @ 10\% }\end{array}$ & $24(0.37)$ & $20(0.37)$ & $19(0.36)$ & $24(0.36)$ & $22(0.36)$ & $22(0.37)$ \\
\hline 3 & Total cost $(1+2)$ & $\begin{array}{c}6434 \\
(100.00)\end{array}$ & $5432(100.00)$ & $\begin{array}{c}5301 \\
(100.00)\end{array}$ & $6623(100.00)$ & $\begin{array}{c}6076 \\
(100.00)\end{array}$ & $\begin{array}{c}5887 \\
(100.00)\end{array}$ \\
\hline 4 & $\begin{array}{l}\text { Gross returns** @ ₹ } 650 \text { for spring and } \\
\text { ₹ } 490 \text { for autumn season }\end{array}$ & 8060 & 3861 & 10836 & 4640 & 8939 & 4165 \\
\hline 5 & Net returns (4-3) & 1626 & -1571 & 5535 & -1983 & 2863 & -1732 \\
\hline 6 & Net returns over variable cost (4-2) & 2264 & -933 & 6317 & -782 & 3547 & -894 \\
\hline 7 & Break- even output (kg) & 3.49 & - & 2.62 & - & 2.65 & - \\
\hline
\end{tabular}

Note: Figures in parentheses indicate percentages of total in the respective category.

${ }^{*}$ The average yield of purchased mulberry leaves per farm for small and large farmers was $1.23 q$ and $3 q$ respectively in the spring season and $0.40 \mathrm{q}$ and $0.44 \mathrm{q}$ respectively in the autumn season; **The average yield of dry cocoons obtained by small and large farmers was per farm was $6.20 \mathrm{~kg}$ and $16.67 \mathrm{~kg}$ respectively for the spring season and $2.05 \mathrm{~kg}$ and $2.84 \mathrm{~kg}$ respectively in the autumn season.

season crop was not profitable while computing returns over variable cost.

\section{Cocoon production function}

Mulberry cocoons were the main crop output realised by sericulturists in the study area being determined by several factors. From the policy point of view, it is essential to quantify the degree of association and cause and effect relationship between the cocoon production on the one hand and numerous factors affecting cocoon production on the other. Such an exercise may help the policy makers and sericulturists to concentrate upon the strategic variables. Here an attempt has been made to examine the input-output relationship for cocoon production on all farms in study area.
Cobb-Douglas production function with seven explanatory variables was used. The results for full model and stepwise function are given in Table 5 and 6 . The results of production function with all variables (Table 5) showed that only silk worms seed $\left(X_{2}\right)$ and numbers of mulberry feedings per day $\left(X_{5}\right)$ were the significant variables affecting the cocoon production. The remaining variables were found to be non-significant hence were not included in the results. The regression coefficients of Cobb-Douglas production function are the direct measures of elasticities of production for the inputs. These coefficients with positive signs and negative signs indicate, ceteris paribus, the percentage increase and or decrease in the dependent variable with 
one per cent increase in the quantity/number of independent variables.

Table 5: Estimates of cocoon production function (all variables) on sample farms

\begin{tabular}{cccc}
\hline $\begin{array}{c}\text { Sl. } \\
\text { No. }\end{array}$ & Particulars & $\begin{array}{c}\text { Regression } \\
\text { coefficient }\end{array}$ & $\begin{array}{c}\text { Standard } \\
\text { error }\end{array}$ \\
\hline 1 & Constant $\left(\mathrm{b}_{0}\right)$ & 3.2419 & - \\
2 & Labour $\left(\mathrm{X}_{1}\right)$ & 0.1900 & 0.1708 \\
3 & Seed $\left(\mathrm{X}_{2}\right)$ & $0.6699^{*}$ & 0.1328 \\
4 & Mulberry $\left(\mathrm{X}_{3}\right)$ & -0.0121 & 0.1047 \\
5 & Experience $\left(\mathrm{X}_{4}\right)$ & 0.0586 & 0.0551 \\
6 & Feeding $\left(\mathrm{X}_{5}\right)$ & $0.3202^{* *}$ & 0.1510 \\
7 & Rearing house $\left(\mathrm{X}_{6}\right)$ & 0.0133 & 0.0401 \\
8 & Coefficient of multiple & 0.71 & - \\
& determination $\left(\mathrm{R}^{2}\right)$ & & \\
9 & $\mathrm{~F}$ - ratio & 21.63 & - \\
10 & $\mathrm{~F}_{\text {tab(6,53) }}$ & 3.254 & - \\
\hline
\end{tabular}

Note: ${ }^{*}$ Indicate significance at $5 \%$ level of significance.

** Indicate significance at $1 \%$ level of significance.

The results of stepwise production function depicted in Table 6 revealed that silk worm seed was the most important variable in affecting the cocoon production. The coefficient attached to this variable indicated that $1 \%$ increase would enhance the cocoon production by 0.75 per cent. Next in importance was the number of mulberry feedings provided per day to the silk worms. This variable shows that $1 \%$ increase in the frequency of silk worms feeding may bring 0.39 per cent increase in the cocoon production. During the survey period it was found that the fresh mulberry leaves fed number of times significantly helped the growth and maturity of silk worms. The sericulturists who could not provide fresh leaves at least four times a day, their crop was delayed by four-five days and got reduced size of cocoons also. The returns to scale for these variables were found to be greater than unity thus indicating a scope for enhancing the use of specified variables on sericultural farms. The coefficient of determination $\left(\mathrm{R}^{2}\right)$ revealed that 69 per cent variation in cocoon production was due to these two variables. The whole analysis concludes that only two variables viz; silk worms seed and daily frequency of mulberry feeding to worms were the important ones in affecting the cocoon production thus enhancing the use of these inputs which may increase the volume of cocoon production significantly on sericultural farms in the study area.

Table 6: Estimates of cocoon production function (significant variables) on sample farms

\begin{tabular}{cccc}
\hline $\begin{array}{c}\text { Sl. } \\
\text { No. }\end{array}$ & Particulars & $\begin{array}{c}\text { Regression } \\
\text { coefficient }\end{array}$ & $\begin{array}{c}\text { Standard } \\
\text { error }\end{array}$ \\
\hline 1 & Intercept $\left(\mathrm{b}_{0}\right)$ & 5.7969 & - \\
2 & Seed $\left(\mathrm{X}_{1}\right)$ & $0.7548^{* *}$ & 0.0922 \\
3 & Feeding $\left(\mathrm{X}_{2}\right)$ & $0.3943^{* *}$ & 0.1405 \\
4 & Coefficient of multiple & 0.69 & - \\
& determination $\left(\mathrm{R}^{2}\right)$ & & - \\
5 & F- ratio & 63.41 & - \\
\hline & $\mathrm{F}_{\text {tab(2,57) }}$ & 4.998 & - \\
\hline
\end{tabular}

Note: ${ }^{* *}$ Indicate significance at $1 \%$ level of significance.

\section{CONCLUSION}

In order to reduce the yield gaps, sericulture implementing agencies such as Department of Sericulture, NGOs and Self- Help Groups should train the farmers to attain potential yield which may indirectly enhance women empowerment as they are playing a major role in this enterprise. The autumn crop was found to give negative returns; therefore farmers should be provided with technology which could reduce the moisture in the rearing room, develop humidity resistant races of silkworms as well as develop varieties of mulberry plantation which may yield good leaves just after rainy season.

\section{REFERENCES}

Alebiosu, I.B. 2012. Sericulture industry and its economic prospects. Continental Journal of Sustainable Development, 3(3): 11-19.

Anonymous. State wise raw silk production in India. http:// www.sericulturecouncil.com [10 ${ }^{\text {th }}$ January, 2016]

Anonymous. District census handbook- Bilaspur.http://www. censusindia.gov.in [10 ${ }^{\text {th }}$ January, 2016]

Anonymous. Statistics- Global silk industry.http://www. inserco.org (15 ${ }^{\text {th }}$ January, 2016)

Chauhan, S.K. 2002. Sericulture - A tool for income and employment generation in Himachal Pradesh. Asian Economic Review, 44(3): 512-520.

Chauhan, S.K., Chouhan, S. and Rattan, M. 2015. A study in the impact of sericulture development programmes in Himachal Pradesh. Indian Journal of Agricultural Economics, 70(3): 289-290.

Utpal, D.K. and Manjit, D. 2010. Scope of Sericulture in AssamA micro-econometric analysis. Journal of Agricultural Extension and Rural Development, 2(6): 106-115. 
Geetha, G.S. 2010. Socio-economic profile of farm women in sericulture activities-A case study. Mysore Journal of Agricultural Sciences, 44(4): 872-876.

Halder, S.R. 1999. Viability of sericulture programme of BRAC: a result of cost-benefit analysis. Bangladesh Journal of Agricultural Economics, 22(2): 99-116.

Kumarsen, P. and Vijay, P.N.B. 2001. Economics of sericulture vis-a-vis competing crops in Erode district of Tamil Nadu. Indian Journal of Sericulture, 40(2): 142-146.

Kumari, V.K.M and Rajan, R.K. 2005. An economic analysis of factors influencing income from commercial chawki rearing centres in Karnataka. Indian Journal of Sericulture, 44(2): 208-211.

Kumari, V.K.M. and Rajan, R.K. 2006. Knowledge and adoption level of technologies by commercial Chawki Rearing Centre owner in Karnataka. Indian Journal of Sericulture, 45(1): 7-10.

Lakshmanan, S. and Geethadevi, R.G. 2005. A comparative analysis of economics of bivoltine and cross- breed cocoon production in Mandya district of Karnataka- A micro level evidence. Indian Journal of Sericulture, 44(2): 179-182.
Parmar, M. 2014. Analysis of sericulture in Himachal Pradesh: A case study of Kangra district of Himachal Pradesh. The International Journal of Humanities $\mathcal{E}$ Social Studies, 2(12): 132-140.

Saraswathi, J.M. and Sumangala, P.R. 2001. Participation of farm women in sericulture enterprise. Indian Journal of Sericulture, 40(1): 86-91.

Srinivasa, G., Chengappa, P.G., Achoth, L., Reddy, K. and Nagaraja, G.N. 2005. Optimum cropping pattern for sericulture-dominant farms in southern dry zone of Karnataka. Agricultural Economics Research Review, 18(10): 117-132.

Vasumathi, B.V., Somashekhar, T.H., Balasubrahmanya, M.H., Krishnaswamy, K.N. and Achoth, L. 2003. A study of the dynamics of cocoon transactions in Karnataka. Agricultural Economics Research Review, 16(2): 116-125.

www.himachal.nic.in [12 ${ }^{\text {th }}$ May, 2016] 
